\title{
Selecting Display Products for Furniture Stores Using Fuzzy Multi-Criteria Decision Making Techniques
}

\author{
Özer Uygun ${ }^{1}$, İlker Güven², Fuat Şimşirir ${ }^{2}$ and Mehmet Emin Aydin ${ }^{3}$ \\ ${ }^{1}$ Sakarya University, Sakarya. 54187, Turkey \\ ${ }^{2}$ Karabuk University, Karabuk 78050, Turkey \\ ${ }^{3}$ University of West of England, Bristol, UK \\ fuatsimsir@karabuk.edu.tr
}

\begin{abstract}
Efficient marketing in which the right products are supplied to the right consumer plays a crucial role for a profitable business in the age of highly accessible and competitive global market. This fact enforces producers to clearly identify and analyze the needs of consumers and to display their products respecting locality based on customers' needs. The position of the business is strengthened within the market and its competiveness increases by supplying and displaying the products suitable to regional consumers' preferences. In this study, an integral fuzzy multi criteria decision making technique is proposed for an effective decision making process to select the most suitable display products to the consumers' needs and preferences. The approach has been applied to identify the most suitable set of modular furniture products to be displayed at a local store that locates in Bursa city of Turkey. The approach uses Fuzzy DEMATEL method to work out the interrelations of chosen criteria, which are weighted with Fuzzy ANP and finally suggest a rank-based list of products with Fuzzy PROMETHEE. The results are verified with the expert view and found very useful.
\end{abstract}

Keywords: Fuzzy DEMATEL, Fuzzy ANP, Fuzzy PROMETHEE, Product Selection, Multi Criteria Decision Making Techniques.

\section{$1 \quad$ Introduction}

Modern marketing environments exhibit interesting behavioral relationships of producers and consumer, where enterprises that offer their products or services to consumers can affect shaping the habits of the consumers while the consumers' behavior affects promoting products. Obviously, the popularity of products among the consumers is one of the main factor in decision-making if a particular product will be kept produced or opted out of the market. Once a product is no longer requested by the consumer to some extent, companies stop produce it. For this reason, products should be attractive to the consumer. The fact that the market has various cultural, ethnic and moral constructs makes it difficult to present the right product to the right consumer.

In such a situation where a precise and careful market analysis requires that the "right products" meet the "right consumers", the choice of the "right product" also has a critical prescription. In this respect, selecting the most suitable set of products to display 
among hundreds of alternative products is not a straightforward decision due to the fact that the complexity of this problem grows with increasing product variety.

The problem taken under consideration requires a firm decision by the decision makers with respect to many criteria, where each imposes constrictions upon the prospective solutions with positive and negative impact. In addition, inter-criteria effects may also bring potential overheads into the decision process. Meanwhile, the resources such as the size of shop floor, labor time are limited and need to be cost-effective. Therefore, such problems are considered for multi-criteria decision making for a firm decision to achieve cost-effective outcome.

Main purpose of this study is to explore how to utilize the market analytics in selecting the best set of display products, which offers the customers the best suiting supply of the product and propose an efficient approach for identifying the right product to the right customer by considering store location and customer expectations with many respects in order to increase the sales. In addition, we also aim to maximize usage of store area, catching target customer group and enhancing competitiveness.

In this study, market analysis is used to consider the above-mentioned problem as a decision problem and to propose an approach based on fuzzy multi-criteria decision making methods integrally used in identifying the best set of modular furniture products to exhibit in a specific department store. Every product group that company produced has been considered as an alternative and evaluated according to the total 22 sub-criteria including investors, regions, concepts, targeted customers, store areas and competitiveness as the main criteria. The fuzzy DEMATEL method was used to reveal the causal and effectual interrelationships of the criteria. This is followed by calculating the weight of each criterion by applying the fuzzy ANP method. The fuzzy PROMETHEE method was finally applied using the final weights and the alternatives were evaluated and ranked.

\section{Literature Review}

Decision problems are rather complicated problems, which require considering a number of decision variables to be evaluated with respect to a number of criteria. There is a relatively rich literature in handled decision problems including multi-criteria decision-making approaches. Multi-criteria decision making techniques are utilized for considering many industrial and social problems to benefit of the analytical perspective gained in decision analysis. Although multi-criteria decision making techniques have very sound track record in solving various problems, there has been no study found on use of multi-criteria decision making approaches used within the scope of market analysis for their products.

The DEMATEL method is a frequently used method to reveal the relations of the criteria with each other. The ANP method is a method that considers the dependencies and feedback for both within the criterion and among the criterion. For this reason, it provides a more realistic approach to the problem of decision making [1]. When the literature is examined, DEMATEL and ANP methods are often used together to complete each other. Pamučar et al. [2] have explained the relationships in the data set by 
applying the DEMATEL method to the data set they used in their work. Uygun and Dede [3] used fuzzy multi-criteria decision making techniques to evaluate the performance of the green supply chain in their work. Relations between the performance evaluation criteria of the green supply chain in their work were revealed using DEMATEL and the fuzzy ANP method was applied considering these relations.

One of the other multi-criteria decision making techniques used in the literature is PROMETHEE. Vulević and Dragović [4] used the PROMETHEE method to rank subwater basins in their work. Gül et al. [5] have addressed the problem of material selection using a fuzzy logic-based PROMETHEE method in their work. Bongo et al. [6] have developed an approach in which air traffic control officers use the DEMATELANP and PROMETHEE II methods for workload stress.

ANP and PROMETHEE are used for many decision problems such as selection of ERP system for small and medium-sized enterprises, to evaluate and select light commercial vehicles for white goods services, to suggest new car-leasing system by comparing it with the existed one [7]-[9].

Efe et al. [10] examined the ergonomic product concept selection using heuristic fuzzy TOPSIS method. They pointed out that using heuristic fuzzy logic would give more accurate results because customers use linguistic expressions in their product preferences. In that study on mobile phone preferences, which products are preferred by consumers in order to guide the producers are presented by the heuristic fuzzy set theory.

\section{Proposed Approach}

In the study, an approach is presented to assess the selection of products to be placed in store by combined fuzzy multi-criteria decision making techniques according to the market demands of the producer company in a particular region. The general steps of the proposed approach are given as in the Fig. 1. Each method uses the obtained data from previous method.

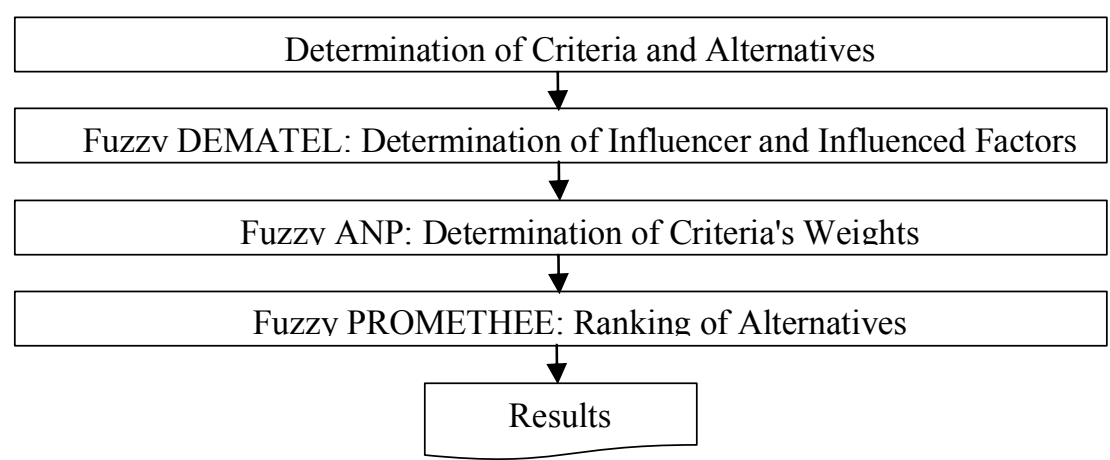

Fig. 1. Main steps of proposed approach for selecting display products in a Furniture Store 


\subsection{Fuzzy Dematel Method}

The DEMATEL method is a model developed by the Geneva Battelle Institute as a method of revealing and analyzing the causality relationship between the factors in the model [11]. However, since it is difficult to quantify the interactions between the factors, the DEMATEL method has difficulty in determining the degree of relation between the factors. In order to come from this predicament, Lin and $\mathrm{Wu}$ have brought their problems fuzzy environment and presented the Fuzzy DEMATEL approach [12].

Step 1: Determination of criteria and creation of fuzzy scale. In the first step, the criteria to be applied should be determined. Two experts' views were taken into account in the determination of the criteria at the relevant firm as given in Fig. 2.

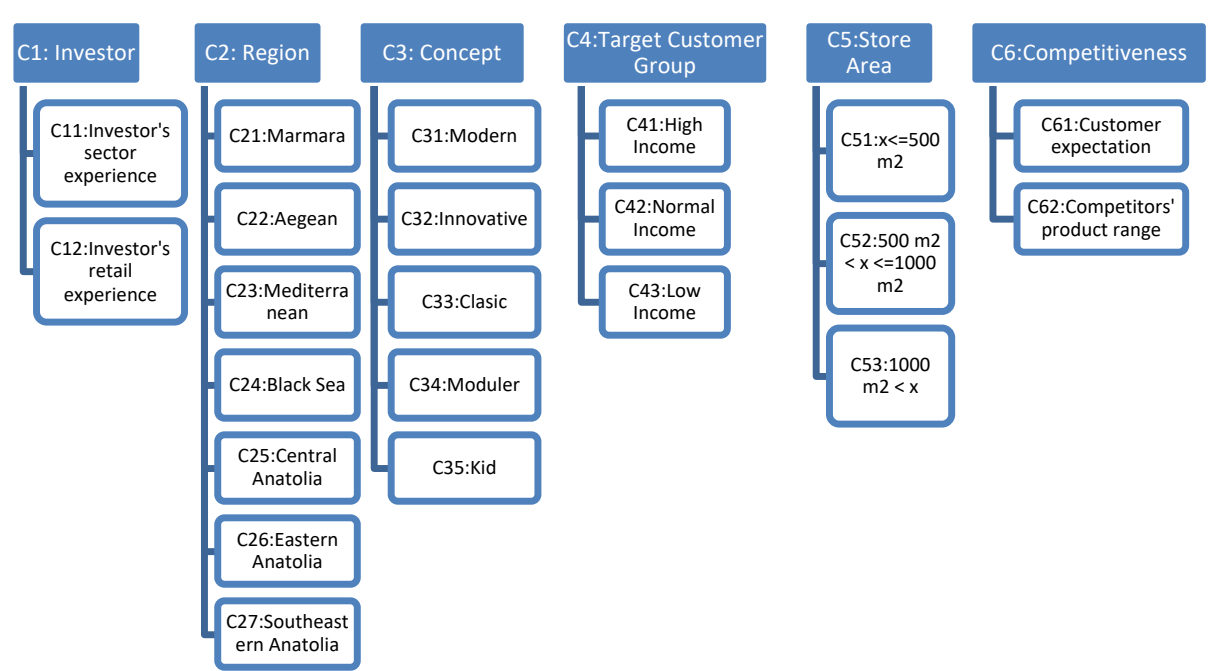

Fig. 2. Criteria for product selection

Step 2: Evaluating the criteria of the decision makers and establishing the direct relation matrix. In this step, $\mathrm{n}$ decision makers are asked to evaluate each criterion with the help of the linguistic expressions given in Table 1.

Table 1. The linguistic expressions and values used for the fuzzy DEMATEL method [13]

\begin{tabular}{ll}
\hline Linguistic Expressions & Linguistic Values \\
\hline Very Low Influence (VLI) & $(0,00 ; 0,00 ; 0,25)$ \\
Low Influence (LI) & $(0,00 ; 0,25 ; 0,50)$ \\
Normal Influence (NI) & $(0,25 ; 0,50 ; 0,75)$ \\
High Influence (HI) & $(0,50 ; 0,75 ; 1,00)$ \\
Very High Influence (VHI) & $(0,75 ; 1,00 ; 1,00)$ \\
\hline
\end{tabular}

As a result of this, $\mathrm{n}$ fuzzy evaluation matrices will be obtained. In order to proceed with the fuzzy DEMATEL process, the opinion of each expert is collected and divided into the number of experts and the fuzzy $\widetilde{Z}$ matrix is obtained [14]. 
The initial direct relation fuzzy matrix contains fuzzy numbers. Here, each $\widetilde{z_{\iota \jmath}}=$ $\left(l_{i j}, m_{i j}, u_{i j}\right)$ is a triangular fuzzy number.

Step 3: Normalize the direct relation fuzzy matrix.

Step 4: After normalized direct relation fuzzy matrix, obtain the total relation fuzzy matrix.

Step 5: Each value of total relation fuzzy matrix in Step 4 are still triangular fuzzy numbers. Defuzzification must be done as directed in the literature to make them a single value.

\subsection{Fuzzy ANP Method}

The ANP method basically has the same structure as the AHP, but it also takes into account the relationships between the criteria. It was proposed by Saaty as an improved version of AHP. Unlike the AHP method, the ANP method aims to make an appropriate choice among the alternatives by evaluating the criteria in the horizontal plane with each other [14]-[17].

As in the DEMATEL method, the ANP method is also expanded by the fuzzy set theory to remove the ambiguity in preferences. In the implementation phase of the fuzzy ANP method, the expansion analysis method proposed by Chang was followed as below [18].

Step 1: Calculate the synthetic expansion value $S_{i}$ dependent on the $\mathrm{i}^{\text {th }}$ goal.

Step 2: Calculate the preference between alternatives.

Step 3: Calculate the likelihood of a convex fuzzy number greater than $\mathrm{k}$ convex fuzzy numbers.

Step 4: Normalize the obtained values.

In this study, the Fuzzy ANP method is used to calculate the weights of the criterion according to the results of the total relation matrix obtained from the Fuzzy DEMATEL method. For the ANP, the linguistic expressions and values given in Table 2 were used during the taking of expert opinions.

Table 2. The linguistic expressions and values used in the fuzzy ANP method

\begin{tabular}{ll}
\hline Linguistic Expressions & Linguistic Values \\
\hline Equally Important (EI) & $(1,1,1)$ \\
Weakly Important (WI) & $(2 / 3,1,3 / 2)$ \\
Strongly Important (SI) & $(3 / 2,2,5 / 2)$ \\
Very Important (VI) & $(5 / 2,3,7 / 2)$ \\
Absolutely Important(AI) & $(7 / 2,4,9 / 2)$ \\
\hline
\end{tabular}

\subsection{Fuzzy Promethee Method}

The combination of the PROMETHEE method with fuzzy logic was performed by Ténoa and Mareschal [19]. There is no change in terms of implementation between PROMETHEE and Fuzzy PROMETHEE methods. The actual difference in the fuzzy PROMETHEE method is the calculations to be done with fuzzy numbers. 
When the fuzzy PROMETHEE calculations are performed, the LR type fuzzy numbers used in Yılmaz and Dağdeviren [20] studies, will be used and the Yager (1981) index will be taken into consideration[21]. Here $\widetilde{F}=(n, a, b)$ is expressed as LR type fuzzy number. All numbers between $(n-a)$ and $(n+b)$ belong to the fuzzy cluster where $a(L)$ and $b(R)$ give the right and left spreading function of the $n$.

Step 1: In this study, the criterion and the weights of them will be obtained from Fuzzy DEMATEL and Fuzzy ANP methods and will form the data matrix with the alternatives. $\mathrm{w}=(\mathrm{w} 1, \mathrm{w} 2 \ldots \mathrm{wn})$ express weights, $\mathrm{c}=(\mathrm{f} 1, \mathrm{f} 2, \ldots, \mathrm{fn})$ express evaluations based on the criteria and $A=(a, b, \ldots, n)$ express alternative as shown in Table 3 . Here, each Fi(n) value is a LR type fuzzy triangular number.

Step 2: There are six types of preferred functions for PROMETHEE. It can be used for implementation by choosing the preference function that best suits the problem structure and best explains the problem. The linear type of preference function will be used in this study as in equation 1 .

Table 3. Promethee initial decision matrix

\begin{tabular}{llllll}
\hline Criteria & $\mathbf{a}$ & $\mathbf{b}$ & $\ldots$ & $\mathbf{n}$ & $\mathbf{w}$ \\
\hline $\mathbf{f 1}$ & $\mathrm{F}_{1}(\mathrm{a})$ & $\mathrm{F}_{1}(\mathrm{~b})$ & $\ldots$ & $\mathrm{F}_{1}(\mathrm{n})$ & w1 \\
$\mathbf{f 2}$ & $\mathrm{F}_{2}(\mathrm{a})$ & $\mathrm{F}_{2}(\mathrm{~b})$ & $\ldots$ & $\mathrm{F}_{2}(\mathrm{~b})$ & w2 \\
$\ldots$ & $\ldots$ & $\ldots$ & $\ldots$ & $\ldots$ & $\ldots$ \\
$\mathbf{f n}$ & $\mathrm{F}_{\mathrm{n}}(\mathrm{a})$ & $\mathrm{F}_{\mathrm{n}}(\mathrm{b})$ & $\ldots$ & $\mathrm{F}_{\mathrm{n}}(\mathrm{n})$ & wn \\
\hline
\end{tabular}

$P(x)=\left\{\begin{array}{cc}0 & n-c \leq q \\ \frac{\tilde{x}(n, a, b)-q}{p-q} & q \leq n-c \text { ve } n+d \leq p \\ 1 & n+d \geq p\end{array}\right.$

Step 3: Based on the preference functions, the common preference functions for alternative pairs can be determined.

Step 4: The obtained matrix consists of fuzzy triangular numbers of the LR type. To defuzzification of such numbers, the Yager index is used.

Step 5: The preference indices of alternatives $a$ and $b$ is calculated. $k$ criteria evaluates $a$ and $b$ alternatives with weights $w_{i}(i=1,2, \ldots, k)$

Step 6: For alternative a, the positive and negative advantages are calculated.

Step 7: Partial priorities specify the position of the alternatives against each other. Here, some alternatives can be compared with each other, while others are not.

Step 8: The PROMETHEE II method calculates the full priority values and allows the alternatives to be evaluated in the same plane by equation 2 . Thus alternatives can be shown in a complete sequence from best to worse.

$$
\Phi(a)=\Phi^{+}(a)-\Phi^{-}(a)
$$

Linguistic expressions and values for Promethee are given in Table 4. 


\section{Case Study and Implementation}

The method proposed in the study was applied to the store opened in Bursa region by the manufacturer which produces modular furniture. Among the 49 alternative products, Fuzzy DEMATEL method was first applied to find out affecting and affected criteria, then Fuzzy ANP method was applied considering the criterion obtained, to determinate weights of criteria, and finally Fuzzy PROMETHEE method was applied to rank alternatives for determining the most appropriate product families for the regional market and consumer demands.

Table 4. The linguistic expressions and values used in the fuzzy PROMETHE method

\begin{tabular}{lcc}
\hline Linguistic Variables & Linguistic Values & $\begin{array}{c}\text { Linguistic Values arranged according } \\
\text { to Yager Index }\end{array}$ \\
\hline Very Poor (VP) & $(0,0,0.15)$ & $(0,0,0)$ \\
Poor (P) & $(0,0.15,0.3)$ & $(0.15,0.15,0.15)$ \\
Medium Poor (MP) & $(0.15,0.3,0.5)$ & $(0.3,0.15,0.2)$ \\
Fair (F) & $(0.3,0.5,0.65)$ & $(0.5,0.2,0.15)$ \\
Medium Good (MG) & $(0.5,0.65,0.8)$ & $(0.65,0.15,0.15)$ \\
Good (G) & $(0.65,0.8,1)$ & $(0.8,0.15,0.2)$ \\
Very Good (VG) & $(0.8,1,1)$ & $(1,0.2,0)$ \\
\hline
\end{tabular}

Table 5. The linguistic expressions of the evaluation of one of the experts for the criteria

\begin{tabular}{ccccccc}
\hline Criteria & I & R & C & TCG & SA & CM \\
\hline I & 0 & VHI & LI & VLI & VHI & VLI \\
R & NI & 0 & VHI & HI & VLI & NI \\
C & LI & VHI & 0 & NI & NI & HI \\
TCG & HI & HI & VHI & 0 & VHI & NI \\
SA & VHI & LI & VHI & LI & 0 & NI \\
CM & NI & HI & VHI & VLI & VLI & 0 \\
\hline
\end{tabular}

Legend: Investor(I), Region(R), Concept(C), Target Customer Group(TCG), Store Area(SA), Competitiveness(CM)

Firstly, in order to reveal the relationships among the alternatives, criteria were suggested and evaluated for a senior white collar who is dealing with franchisers and interior designers who are responsible for the product's location in the store. The linguistic expressions belonging to one of the experts are given in Table 5. The evaluations made by the two experts are given in Table 6 with the mean values.

Table 6. Both experts' evaluations are the resulting direct relation fuzzy matrix (some parts)

\begin{tabular}{c|ccc|ccc|ccc}
\hline Criteria & \multicolumn{3}{|c|}{$\mathbf{I}$} & \multicolumn{3}{|c|}{$\mathbf{R}$} \\
\hline $\mathbf{I}$ & 0 & 0 & 0 & 0,375 & 0,625 & 0,875 & 0 & 0,125 & 0,375 \\
$\mathbf{R}$ & 0,375 & 0,625 & 0,875 & 0 & 0 & 0 & 0,75 & 1 & 1 \\
$\mathbf{C}$ & 0 & 0,25 & 0,5 & 0,75 & 1 & 1 & 0 & 0 & 0 \\
\hline
\end{tabular}

The direct relation fuzzy matrix is normalized. Then, the total relation fuzzy matrix is obtained as in Table 7. 
Table 7. Total relation fuzzy matrix (some parts)

\begin{tabular}{c|ccc|ccc|ccc}
\hline Criteria & \multicolumn{3}{|c|}{ I } & \multicolumn{3}{c|}{ R } & \multicolumn{3}{c}{ C } \\
\hline I & 0,0342 & 0,127 & 0,516 & 0,105 & 0,266 & 0,751 & 0,046 & 0,19 & 0,645 \\
R & 0,1094 & 0,294 & 0,846 & 0,077 & 0,255 & 0,81 & 0,219 & 0,434 & 0,945 \\
C & 0,0426 & 0,236 & 0,76 & 0,221 & 0,44 & 0,957 & 0,091 & 0,271 & 0,743 \\
\hline
\end{tabular}

Defuzzified total relation matrix is obtained, and shown in Table 8 . The threshold value is determined as 0.353 according to the expert opinions.

Table 8. Defuzzified total relation matrix

\begin{tabular}{ccccccc}
\hline Criteria & I & $\mathbf{R}$ & $\mathbf{C}$ & TCG & SA & CM \\
\hline I & 0,201 & 0,347 & 0,268 & 0,191 & $\mathbf{0 , 3 5 3}$ & 0,187 \\
R & $\mathbf{0 , 3 8 6}$ & 0,349 & $\mathbf{0 , 5 0 8}$ & 0,344 & 0,309 & $\mathbf{0 , 3 7 3}$ \\
C & 0,319 & $\mathbf{0 , 5 1 5}$ & 0,344 & $\mathbf{0 , 3 5 6}$ & 0,298 & $\mathbf{0 , 4 1 0}$ \\
TCG & $\mathbf{0 , 4 2 6}$ & $\mathbf{0 , 5 3 8}$ & $\mathbf{0 , 5 3 2}$ & 0,253 & $\mathbf{0 , 4 3 7}$ & $\mathbf{0 , 3 5 5}$ \\
SA & $\mathbf{0 , 4 1 7}$ & $\mathbf{0 , 4 2 5}$ & $\mathbf{0 , 4 6 9}$ & 0,288 & 0,244 & 0,313 \\
CM & 0,29 & $\mathbf{0 , 4 2 3}$ & $\mathbf{0 , 4 4 8}$ & 0,208 & 0,251 & 0,215 \\
\hline
\end{tabular}

After obtaining cause and effect relationship by the Fuzzy DEMATEL method, pairwise comparisons were made to calculate the criteria's weights by applying the Fuzzy ANP method. For example, the Investor criterion, as seen in Table 8, is affecting the Store Area criterion. The sub-criteria of the store area C51, C52 and C53 are evaluated by taking into account the sub criteria of the investor. In Table 9, one of the experts' evaluations is given for the store area according to the Investor Sector Experience sub criterion.

Table 9. Taking into consideration the investor sector experience criterion, the linguistic expression of the expert evaluation for the store area

\begin{tabular}{cccc}
\hline Criteria & $($ C51) & (C52) & (C53) \\
\hline$($ C51) & EI & & \\
$($ C52) & EI & EI & EI \\
$($ C55) & SI & SI & \\
\hline
\end{tabular}

In Table 10, fuzzy number equivalents are given for this evaluation.

Table 10. Taking into consideration the investor sector experience criterion, the fuzzy values of the expert evaluation for the store area

\begin{tabular}{c|ccc|ccc|ccc}
\hline Criteria & \multicolumn{3}{|c|}{ (C51) } & \multicolumn{3}{c|}{ (C52) } & \multicolumn{3}{c}{ (C53) } \\
\hline (C51) & 1 & 1 & 1 & 1 & 1 & 1 & 0,4 & 0,5 & 0,667 \\
$(\mathbf{C 5 2})$ & 1 & 1 & 1 & 1 & 1 & 1 & 0,4 & 0,5 & 0,667 \\
$(\mathbf{C 5 3})$ & 1,5 & 2 & 2,5 & 1,5 & 2 & 2,5 & 1 & 1 & 1 \\
\hline
\end{tabular}

For each criterion above the threshold value, the sub-criteria were evaluated by the experts, and then the local weights calculated by taking the geometric mean of the expert opinions. The results obtained are shown in Table 11. Similarly, all calculations were done for all criteria and sub-criteria that passed the threshold in the total relation matrix as a result of the Fuzzy Dematel method. 
Table 11. Considering the investor sector experience criterion, the geometric mean and calculated weights of the expert assessments made for the store area

\begin{tabular}{l|ccc|ccc|ccc|c}
\hline $\begin{array}{l}\text { Cri- } \\
\text { teria }\end{array}$ & \multicolumn{3}{|c|}{ (C51) } & \multicolumn{3}{c|}{ (C52) } & & (C53) & & $\begin{array}{c}\text { Weights } \\
\left(\mathbf{W}_{\text {i }}\right)\end{array}$ \\
\hline (C51) & 1 & 1 & 1 & 0,816 & 1 & 1,225 & 0,338 & 0,408 & 0,516 & $\mathbf{0 , 0 0 5}$ \\
$(\mathbf{C 5 2})$ & 0,8165 & 1 & 1,225 & 1 & 1 & 1 & 0,775 & 1 & 1,291 & $\mathbf{0 , 2 7 8}$ \\
$(\mathbf{C 5 3})$ & 1,9365 & 2,449 & 2,958 & 0,775 & 1 & 1,291 & 1 & 1 & 1 & $\mathbf{0 , 7 1 7}$ \\
\hline
\end{tabular}

The results obtained are given in the unweighted matrix as in Table 12, and limit super matrix is given as in Table 13.

Table 12. Unweighted super matrix

\begin{tabular}{ccccccccccc}
\hline & C11 & C12 & C21 & C22 & $\ldots$ & C51 & C52 & C53 & C61 & C62 \\
\hline C11 & 0 & 0 & 0,924 & 0,672 & $\ldots$ & 0,5 & 0,672 & 0,672 & 0 & 0 \\
C12 & 0 & 0 & 0,076 & 0,328 & $\ldots$ & 0,5 & 0,328 & 0,328 & 0 & 0 \\
C21 & 0 & 0 & 0 & 0 & $\ldots$ & 0,083 & 0,105 & 0,091 & 0,23 & 0,163 \\
$\vdots$ & $\ldots$ & $\ldots$ & $\ldots$ & $\ldots$ & $\ldots$ & $\ldots$ & $\ldots$ & $\ldots$ & $\ldots$ & $\ldots$ \\
C53 & 0,717 & 0,377 & 0 & 0 & $\ldots$ & 0 & 0 & 0 & 0 & 0 \\
C61 & 0 & 0 & 0,662 & 0,924 & $\ldots$ & 0 & 0 & 0 & 0 & 0 \\
C62 & 0 & 0 & 0,338 & 0,076 & $\ldots$ & 0 & 0 & 0 & 0 & 0 \\
\hline
\end{tabular}

Table 13. Limit super matrix

\begin{tabular}{ccccccccccc}
\hline & $\mathbf{C 1 1}$ & $\mathbf{C 1 2}$ & $\mathbf{C 2 1}$ & $\mathbf{C 2 2}$ & $\ldots$ & $\mathbf{C 5 1}$ & $\mathbf{C 5 2}$ & $\mathbf{C 5 3}$ & $\mathbf{C 6 1}$ & $\mathbf{C 6 2}$ \\
\hline C11 & 0,097 & 0,097 & 0,097 & 0,097 & $\ldots$ & 0,097 & 0,097 & 0,097 & 0,097 & 0,097 \\
$\mathbf{C 1 2}$ & 0,047 & 0,047 & 0,047 & 0,047 & $\ldots$ & 0,047 & 0,047 & 0,047 & 0,047 & 0,047 \\
C21 & 0,038 & 0,038 & 0,038 & 0,038 & $\ldots$ & 0,038 & 0,038 & 0,038 & 0,038 & 0,038 \\
$\vdots$ & $\ldots$ & $\ldots$ & $\ldots$ & $\ldots$ & $\ldots$ & $\ldots$ & $\ldots$ & $\ldots$ & $\ldots$ & $\ldots$ \\
C53 & 0,095 & 0,095 & 0,095 & 0,095 & $\ldots$ & 0,095 & 0,095 & 0,095 & 0,095 & 0,095 \\
C61 & 0,098 & 0,098 & 0,098 & 0,098 & $\ldots$ & 0,098 & 0,098 & 0,098 & 0,098 & 0,098 \\
C62 & 0,069 & 0,069 & 0,069 & 0,069 & $\ldots$ & 0,069 & 0,069 & 0,069 & 0,069 & 0,069 \\
\hline
\end{tabular}

After calculating the weights of the criteria using the fuzzy ANP method, the alternatives were evaluated to apply the Fuzzy PROMETHEE method according to the criteria using the linguistic expressions given in Section 3.3. Table 14 lists the linguistic values of one of the experts for the alternatives. Similarly, after taking other expert opinions, a fuzzy initial decision matrix for Fuzzy PROMETHEE was generated by calculating the average of expert opinions. Pairwise comparisons were made for each alternative using the preference function given in equation 1 , then common preference function is used, and the resulting matrix of common preference functions was refined using the Yager index. Following steps applied from Section 3.3 and finally, full priority values are calculated using equation 2 and the alternatives are listed as in Table 15. According to this table, among the all alternatives, the alternatives suitable for the store to be opened in Bursa province are Product Family(PF) 30, PF 48, PF 26, PF 18 and so on. 
Table 14. Linguistic values of first five product family for Investor criteria

\begin{tabular}{l|ccc|ccc}
\hline \multirow{2}{*}{ Alternatives } & \multicolumn{5}{|c}{ Investor (C1) } \\
\cline { 2 - 6 } & \multicolumn{7}{|c|}{ C11 } & & \multicolumn{3}{c}{ C12 } \\
\cline { 1 - 5 } PF.001 & 0,5 & 0,2 & 0,15 & 0,65 & 0,15 & 0,15 \\
PF.002 & 0,65 & 0,15 & 0,15 & 0,65 & 0,15 & 0,15 \\
PF.003 & 0,65 & 0,15 & 0,15 & 0,65 & 0,15 & 0,15 \\
PF.004 & 0,8 & 0,15 & 0,2 & 0,65 & 0,15 & 0,15 \\
PF.005 & 0,15 & 0,15 & 0,15 & 0,5 & 0,2 & 0,15 \\
\hline
\end{tabular}

Legend: Product Family(PF)

Table 15. List of the selected product families by result of Fuzzy Promethee

\begin{tabular}{ccccc}
\hline Rank & Alternatives & Ф+ & Ф- & ФNET \\
\hline $\mathbf{1}$ & PF.030 & 0,186 & 0,018 & $\mathbf{0 , 1 6 7 9}$ \\
$\mathbf{2}$ & PF.048 & 0,182 & 0,022 & $\mathbf{0 , 1 6 0 0}$ \\
$\mathbf{3}$ & PF.026 & 0,192 & 0,035 & $\mathbf{0 , 1 5 7 0}$ \\
$:$ & $\ldots$ & $\ldots$ & $\ldots$ & $\ldots$ \\
$\mathbf{4 8}$ & PF.020 & 0,012 & 0,301 & $\mathbf{- 0 , 2 8 9 3}$ \\
$\mathbf{4 9}$ & PF.014 & 0,006 & 0,348 & $\mathbf{- 0 , 3 4 2 1}$ \\
\hline
\end{tabular}

Table 16 shows sales of two stores in the same area. Store 1's product selection was done according to given approach in this paper and Store 2's products were decision of the responsible person. Store 1's selected products cover $\% 66$ sales of total sales of the store where Store 2 's product sales are only $\% 31$ of total sales of the store. It can be seen that catching customer with the right products can increase the sales.

Table 16. List of the selected product families sales

\begin{tabular}{cccc}
\hline Rank & Alternatives & $\begin{array}{c}\text { Store 1 Sales } \\
\text { (pcs) }\end{array}$ & $\begin{array}{c}\text { Store 2 Sales } \\
\text { (pcs) }\end{array}$ \\
\hline $\mathbf{1}$ & PF.030 & 19 & $\begin{array}{c}\text { non-exhibi- } \\
\text { ted }\end{array}$ \\
$\mathbf{2}$ & PF.048 & 11 & 16 \\
$\mathbf{3}$ & PF.026 & 12 & $\begin{array}{c}\text { non-exhibi- } \\
\text { ted }\end{array}$ \\
$\mathbf{4}$ & PF.018 & 8 & 9 \\
$\mathbf{5}$ & PF.044 & 45 & 32 \\
$\mathbf{6}$ & PF.035 & 38 & 40 \\
$\mathbf{7}$ & PF.033 & 55 & 24 \\
$\mathbf{8}$ & PF.038 & 27 & non-exhibi- \\
ted \\
$\mathbf{9}$ & PF.016 & 83 & non-exhibi- \\
ted \\
$\mathbf{1 0}$ & PF.037 & 19 & non-exhibi- \\
total sales of selected PF & $\mathbf{3 1 7}$ & $\mathbf{1 2 1}$ \\
Total sales of store & $\mathbf{4 7 9}$ & $\mathbf{3 8 7}$ \\
Total sales of selected PF over \\
total sales (\%)
\end{tabular}




\section{Conclusion}

The practice and research prove that the use of multi-criteria decision making techniques helps making firm decision to produce more beneficial outputs as each technique in this regard imposes use of analytical and effective comparative processes. Furthermore, embracing fuzzy logic to empower these techniques even further helps generate more realistic solutions with high reliability as it brings human experts' view in-theloop for evaluations and judgments. In this study, an approach using a framework of multiple fuzzy multi-criteria decision making techniques is implemented for solving display products selection problems. The approach is applied to a real problem case that suggests a set of products to exhibit in a department store recently opened in Bursa province Turkey, which sells modular home and office furniture. The proposed approach has been successfully applied and the results were verified with human expert view; then a substantial list of display products are suggested to the company for other stores.

\section{References}

[1] N. Ömürbek and A. Şimşek, "Analitik Hiyerarşi Süreci ve Analitik Ağ Süreci Yöntemleriyle Online Alışveriş Site Seçimi," Journal of Management and Economics Research, no. 22, pp. 306-306, Jan. 2014.

[2] D. Pamučar, M. Mihajlović, R. Obradović, and P. Atanasković, "Novel approach to group multi-criteria decision making based on interval rough numbers: Hybrid DEMATEL-ANP-MAIRCA model," Expert Systems with Applications, vol. 88, pp. 58-80, Dec. 2017.

[3] Ö. Uygun and A. Dede, "Performance evaluation of green supply chain management using integrated fuzzy multi-criteria decision making techniques," Computers \& Industrial Engineering, vol. 102, pp. 502-511, Dec. 2016.

[4] T. Vulević and N. Dragović, "Multi-criteria decision analysis for subwatersheds ranking via the PROMETHEE method," International Soil and Water Conservation Research, vol. 5, no. 1, pp. 50-55, Mar. 2017.

[5] M. Gul, E. Celik, A. T. Gumus, and A. F. Guneri, "A fuzzy logic based PROMETHEE method for material selection problems," Beni-Suef University Journal of Basic and Applied Sciences, Jul. 2017.

[6] M. F. Bongo, K. M. S. Alimpangog, J. F. Loar, J. A. Montefalcon, and L. A. Ocampo, "An application of DEMATEL-ANP and PROMETHEE II approach for air traffic controllers' workload stress problem: A case of Mactan Civil Aviation Authority of the Philippines," Journal of Air Transport Management, Oct. 2017.

[7] H. S. Kilic, S. Zaim, and D. Delen, "Selecting 'The Best' ERP system for SMEs using a combination of ANP and PROMETHEE methods," Expert Systems with Applications, vol. 42, no. 5, pp. 2343-2352, Apr. 2015.

[8] N. Ömürbek, M. Karaatl1, H. Eren, and B. Şanl,, "AHP Temelli PROMETHEE Sıralama Yöntemi ile Hafif Ticari Araç Seçimi," Süleyman Demirel 
Üniversitesi İktisadi ve İdari Bilimler Fakültesi Dergisi, vol. 19, no. 4, pp. $47-$ 64, Dec. 2014.

[9] E. Öztoprak, "Kiralama Yoluyla Araba Temin Eden Bir İşletmede AHP Yöntemi Uygulaması," Atatürk Üniversitesi Sosyal Bilimler Enstitüsü Dergisi, vol. 18, no. 2, pp. 337-348, Oct. 2014.

[10] B. Efe, F. Boran, and M. Kurt, "Sezgisel Bulanık Topsis Yöntemi Kullanılarak Ergonomik Ürün Konsept Seçimi," Mühendislik Bilimleri ve Tasarım Dergisi, vol. 3, no. 3, pp. 433-440, Dec. 2015.

[11] S. Karaoğlan, "DEMATEL Ve VIKOR Yöntemleriyle Dış Kaynak Seçimi: Otel İşletmesi Örneği," Akademik Bakış Uluslararası Hakemli Sosyal Bilimler Dergisi, no. 55, pp. 9-24, Sep. 2016.

[12] C.-J. Lin and W.-W. Wu, "A causal analytical method for group decisionmaking under fuzzy environment," Expert Systems with Applications, vol. 34, no. 1, pp. 205-213, Jan. 2008.

[13] A. Organ, "Bulanık Dematel Yöntemiyle Makine Seçimini Etkileyen Kriterlerin Değerlendirilmesi," Çukurova Üniversitesi Sosyal Bilimler Enstitüsü Dergisi, vol. 22, no. 1, pp. 157-172, Dec. 2013.

[14] Ö. Uygun and A. Dede, "Performance evaluation of green supply chain management using integrated fuzzy multi-criteria decision making techniques," Computers \& Industrial Engineering, vol. 102, pp. 502-511, Dec. 2016.

[15] E. Aksakal and M. Dağdeviren, "ANP Ve DEMATEL Yöntemleri Ile Personel Seçimi Problemine Bütünleşik Bir Yaklaşım.," Gazi Üniv. Müh. Mim. Fak. Der., vol. 25, no. 4, pp. 905-913, 2010.

[16] G. N. Yücenur, "Turizm Sektöründe Strateji Seçimi için Bulanık Veriler Yardımıyla Hiyerarşik Ağ Modeli ve SWOT Analizi: Türkiye Örneği," Sakarya Üniversitesi Fen Bilimleri Enstitüsü Dergisi, vol. 21, no. 5, Sep. 2017.

[17] A. Dargi, A. Anjomshoae, M. R. Galankashi, A. Memari, and M. B. M. Tap, "Supplier Selection: A Fuzzy-ANP Approach," Procedia Computer Science, vol. 31, pp. 691-700, 2014.

[18] D.-Y. Chang, "Applications of the extent analysis method on fuzzy AHP," European Journal of Operational Research, vol. 95, no. 3, pp. 649-655, Dec. 1996.

[19] J. F. Le Téno and B. Mareschal, "An interval version of PROMETHEE for the comparison of building products' design with ill-defined data on environmental quality," European Journal of Operational Research, vol. 109, no. 2, pp. 522 529, Sep. 1998.

[20] B. Yılmaz and M. Dağdeviren, "Ekipman Seçimi Probleminde PROMETHEE ve Bulanık PROMETHEE Yöntemlerinin Karşılaştırmalı Analizi," Gazi Üniversitesi Mühendislik-Mimarlık Fakültesi Dergisi, vol. 25, no. 4, pp. 811$826,2010$.

[21] A. Organ, "Bulanık Dematel Yöntemiyle Makine Seçimini Etkileyen Kriterlerin Değerlendirilmesi," Çukurova Üniversitesi Sosyal Bilimler Enstitüsü Dergisi, vol. 22, no. 1, pp. 157-172, Dec. 2013. 